\title{
News and Notices
}

\section{Jesuit Scientists in Science-Fiction Novels*}

\author{
Agustín Udías, S.J. \\ Universidad Complutense \\ agustinudias@gmail.com
}

\begin{abstract}
The appearance of Jesuit scientists in science-fiction novels, often as the main characters, is an interesting and little-known fact. Some have even suggested that this feature may characterize a specific sub-genre of such novels. The quality and the themes vary greatly, and it is not clear what moves authors to include Jesuits. This article reviews ten of these novels, noting their great variety in plot and approach, as well as the frequent use of space travel and contact with intelligent aliens. In general, the presence of Jesuit characters allows the authors to introduce a religious perspective, but can also be interpreted as a recognition of the Jesuit tradition in scientific fields.
\end{abstract}

\section{Keywords}

science-fiction - Jesuit scientists - space Jesuits - Jesuit astronomers - alien religion other worlds - Jesuit novels - pace journeys

\section{Science-Fiction and Jesuits}

Science-fiction novels constitute a literary genre, which in general deals with situations resulting from scientific and technological advances projects, in a

\footnotetext{
* An earlier version of this article in Spanish was published in Razón yfe 276 (2018): 203-11.

(C) AGUSTÍn UDÍAS, 2019 | DOI:10.1163/22141332-00601010

This is an open access article distributed under the terms of the prevailing CC-BY-NC license at the time of publication.
} 
more or less realistic form, into a distant future. To define the genre with more precision is difficult, given the great variety of plots and themes: for example, a distant future dominated by the scientific progress of artificial intelligence, or space travel to faraway planets, inhabited by alien intelligent beings. According to David Pringle, science-fiction is a form of fantastic fiction that exploits the imaginative perspectives of modern science. ${ }^{1}$ There are many types and sub-genres of science fiction, but in all of them science and technology, real or invented, play a key role. These works often deal with exotic worlds, aliens, intelligent robots, mutants, and other predicted or imagined beings, together with speculations - often not very realistic - about scientific and technological progress and the resulting consequences for human beings.

Curiously, in some of these novels, Jesuit scientists appear as the main characters. Their presence may correspond in part to the popular identification of an ecclesiastic scientist with a Jesuit. For this reason, some authors of sciencefiction novels find it attractive to present Jesuits as their main or secondary characters, as this allows them to deal with subjects related with religion. In some of these novels, usually taking place in a distant future, Jesuits take part in space travel. For this reason, Anna Tschetter proposes that "Jesuits in Space" be regarded as a sub-genre of these novels: "One of my favourite sub-genres of sci-fi (or perhaps a sub-sub-genre) is what my family and some friends like to call 'Jesuits in Space'. It's a small genre; not many people outside of the Christian publishing world write a lot about missionaries and evangelism."2 Greyson Clary affirms that for science-fiction authors Jesuits, considered as mystics and scientists, are good leading characters and "because-historically-it's been possible to believe anything about them, no matter how outlandish."3

Guy Consolmagno, S.J., director of the Vatican Observatory takes a more critical and rather negative view of these novels. He affirms that

I can't enjoy a book if it gets too many things wrong that the author should have been able to get right. I don't mind if their speculated future turns out to be impossible [...]. But when they get their philosophy or history or science wrong out of laziness, prejudice, or ignorance, then I don't

1 Damien Broderick and Paul di Filippo, Science Fiction the 101 Best Novels, 1985-2010 (New York: Nonstop Press, 2012), 8.

2 Anna Tschetter, "Jesuits in Space, or a Sci-Fic Subgenre Examining Religion's Failings," http// womenwriteaboutcomics.com/2015/08/04/Jesuits-in-space-or-a sci-fic-sub-genre-examining -religions- failings/ (accessed December 2018).

3 Grayson Clary, "Why Sci-Fi has so Many Catholics," www.theatlantic.com/technology/ archive/2015/11/why-are-there-so-many-catholics-in-science-fiction/41499o/ (accessed December 2018). 
trust anything else the author might want to tell me. In science fiction, I am willing to suspend my disbelief of one or another scientific principle. But I can't suspend my belief of how human beings actually behave. ${ }^{4}$

However, notwithstanding Consolmagno's criticism, the presence of Jesuits in some of these novels is an interesting subject and deserves fuller consideration. There can be no doubt that their presence shows, first of all, a certain implicit recognition of the Jesuit scientific tradition. Apart from the Jesuits, no other group in the Catholic Church has had from its founding such interest, not only individual but also institutional, in the natural sciences, and this continues to this day. Science occupies an important place in the educational work of Jesuit colleges and universities, the order's main apostolic work. In addition, in modern times, Jesuits established a worldwide network of astronomical and geophysical observatories, some of them still active. ${ }^{5}$

\section{The Novels}

The best known science-fiction novels featuring Jesuits as leading characters are without doubt those by Mary Doria Russell, The Sparrow (1997) and its sequel, Children of God (1998). ${ }^{6}$ The first part tells how, after a musical signal has been detected from a distant planet, the Jesuits' superior general decides to organize a space expedition to discover the civilization that sent it. Four Jesuits and four laymen (two of them women) form the team, commanded by Fr. D. W. Yarbrough, who had been a marine commander before joining the Jesuits. The leading character is Emilio Sandoz, a Puerto Rican Jesuit philologist. On the planet, named Rakhat, they find two intelligent species "Jana'ata" and "Runa," the first domineering and aggressive, actually feeding on the more numerous, subservient Runa. After all kinds of hardships, which only Sandoz and one of the women survive, the Jesuit manages to return to Earth.

The second novel, Children of God, recounts the story of the only woman survivor, Sofia Mendes, who remains on the planet living with the Runa, and of Sandoz who, after returning to Earth, is not able to overcome the terrible experiences he has suffered with the Jana'ata, who had made him a sexual

4 Guy Consolmagno, "A Jesuit Astronomer's Guide to Avoiding Awful Science Fiction," http:// www.uscatholic.org/articles/201503/jesuit-astronomer\%E2\%80\%99s-guide-avoiding-awful -science-fiction-29906 (accessed December 2018).

5 Agustín Udías, Jesuit Contribution to Science: A History (Dordrecht: Springer, 2015).

6 Mary D. Russell, The Sparrow (London: Black Swan, 1997) and Children of God (New York: Facett Books, 1998). 
slave. Though he leaves the Jesuit order, he is forced to participate in a second journey organized by the Society and the mafia, which is pursuing commercial interests. In the meantime, important changes have taken place in the relation between the two species on the planet, as the Runa, led by Sofia, successfully revolt against the Jana'ata. The situation on the planet changes radically with the ascendancy of the Runa, and Sandoz at last returns to Earth.

In James Blish's novel A Case of Conscience (1958), the leading character is Ramón Ruiz Sánchez, a Peruvian Jesuit biologist. ${ }^{7}$ It is noteworthy that, as in Russell's novels, the Jesuit protagonist is from Latin America. Fr. Ruiz Sánchez finds himself working with a group of scientists on Lithia, an extrasolar planet inhabited by a type of large intelligent kind of reptiles, which have developed a beautiful, curious, and happy civilization. The central point is that the "Lithians" do not have any sense of good and evil, acting always according to reason, impervious to any type of religious or ethical sense or faith. This deeply concerns Fr. Ruiz-Sánchez and creates in him the titular case of conscience: can one have perfect ethical behavior without any religion? He even asks whether these beings may have been created by the devil himself. On his return journey to Earth, he receives as a gift from a Lithian friend a fertilized, living egg to take with him. The second part of the novel recounts the problems that the newborn Lithian, once an adult, causes the Jesuit. By means of a very popular television program the Lithian extends his more radical rationalist ideas until he returns to his native planet. The situation leads to an unforeseen end with the intervention of the pope, who suspects Ruiz of manichaeism and orders him to perform an exorcism on the planet, creating a new case of conscience. Finally, Ruiz's exorcism unexpectedly results in the destruction of the planet.

Two novels introduce the subject of the star of Bethlehem. Arthur C. Clarke, in the short story The Star (1955), written in the first person, presents the reflections of a Jesuit astrophysicist (his name is not given), responsible for an expedition to Nebula Phoenix, three thousand lightyears from Earth, to study the remains of a supernova. ${ }^{8}$ There, the expedition discovers a lost planet that has survived the explosion of its star. On the now-deserted planet, they find a bunker where the last inhabitants had left information about their advanced and marvelous civilization (now destroyed). The Jesuit realizes after a few calculations that this supernova was in fact the star of Bethlehem, and asks himself how the star that had destroyed such a wondrous civilization could have been used to announce the birth of Christ. In The Magi (2009), by Damien

7 James Blish, A Case of Conscience (Nueva York: Ballantine, 1958).

8 Arthur C. Clarke, "The Star," in The Nine Billion Names of God: The Best Short Stories of Arthur C. Clarke (New York: Signet, 1974), 235-40. 
Broderick, Jesuits have been expelled from the Earth in a distant future and the last four hundred members of the Society live exiled in a large spaceship. ${ }^{9}$ Raphael Silverman, a Jesuit physicist of Jewish background, accompanied by three other Jesuits, descends in a small spacecraft to a deserted planet, where they find an abandoned city. After a series of adventures on the planet, Silverman discovers a message left by the people of the planet who, after seeing the star of Bethlehem and interpreting its meaning, had all left in spaceships in search of the announced Savior.

A very different subject is offerred in the novel by Hilbert Schenck, The Theology of Water (1982).10 Thomas Feeney, a Jesuit geophysicist who had participated in several space expeditions—so that the press calls him "God's astronaut" - takes part in a journey organized by NASA to Titan, a satellite of Saturn. Although they do not find life, the main aim of the journey, they discover that water has very different properties from those on Earth. However, as the astronauts come into contact with the environment of Titan, the properties of the water begin to change and become like those it has on Earth, as if they existed as a function of man's contact. This seems to show, as a theological consequence, that the properties of water depend on man's use of them and implies that the whole of creation is so oriented. In Dante Dreams (2003) by Stephen Baxter, the situation is stranger. ${ }^{11}$ In the first place, the Jesuit is a woman, Eva Himmelfarb, an expert in organic computation who belongs to the first generation of women-priests. Secondly, Eva is dead, after having committed suicide because of the results of her complicated biological research. In consequence, the Vatican establishes an inquiry, which includes an ecclesiastical member of the Pontifical Academy of Sciences and an agnostic woman journalist, into the motives of her suicide. In the inquiry a virtual representation of the deceased is produced to undergo an interrogation. The interrogation is full of references from Dante's Divine Comedy, linked with Eva's strange biological research. Finally, the ecclesiastic gives the virtual Jesuit Eva his absolution.

Even stranger is The Priest's Tale: The Man Who Cried God (2004), part of the novel Hyperion by Dan Simmons. ${ }^{12}$ The story takes place far in the future, with humanity spread over the galaxy under a central government called the

9 Damien Broderick, "The Magi," in Alan Ryan, ed., Perpetual Light (New York: Warner Books, 1982), 302-44.

$10 \quad$ Hilbert Schenck, "The Theology of Water," in Alan Ryan, ed., Perpetual Light (New York: Warner Books, 1982), 170-88.

11 Stephen Baxter, "Dante Dreams," in Phase Space (London: Harper-Collins, 2003) 86-103.

12 Dan Simmons, "The Priest's Tale: The Man Who Cried God," in Hyperion (London: Orion Publications, 2004), 23-98. 
Hegemony. Paul Doré is a Jesuit archaeologist, ethnologist, and theologian who after some controversial archeological research in the planet Armaghast, decides to travel to Hyperion, a distant world, home to a mysterious entity known as the "Shrike" now worshipped by many humans. His aim is to study a littleknown human group called the "Bikura," who are connected to the origin of the Shrike cult. On the journey to Hyperion, Doré is accompanied by Lenar Hoyt, a young priest (not specified as a Jesuit), who some years later will return to find out that Doré has died. Hoyt finds Doré's journal, which constitutes the main part of the Tale. The journal describes the strange events during Doré's contact with the Bikura, his discovery of an old "basilica," and the secret of the inhabitants-the "cruciform," a parasitic worm that repeatedly resurrects them after death at the cost of diminished intelligence and gender difference. To their horror, both Doré and Hoyt are infected by the parasite, with much of the subsequent "Hyperion Cantos" series dealing with Catholicism's relationship with the "cruciform."

In another short story, The Word to Space (1976) by Winston P. Sanders, James Moriarty, a Jesuit geologist from Loyola University in Los Angeles, tries to give an answer to messages from Akron, a planet at twenty-five light years distance..$^{13}$ The planet is ruled by a theocratic totalitarian government and the messages contain religious propaganda, which has begun to be used by religious sects on Earth. The main part of the story comprises the conversations between Moriarty and the officials in charge of the station that received the messages. Moriarty tries to convince them to send the answers he has elaborated in order to help the people of the planet reform their religious conceptions and practices. After seventy-five years, news is received that Moriarty's proposals have been accepted to the benefit of the situation on the planet, including the separation between the civil and religious authorities.

A novel of fanciful character, in-between satire and the absurd, is Towing Jehovah (1994) by James Morrow. ${ }^{14}$ The novel recounts the aftermath of God's death: his corpse, in the typical figure of white bearded old man-but two miles long! - - is found drifting in the ocean near the equator. Angels announce that the corpse must be towed to the North Pole, where they have prepared a tomb in the ice. One of the leading characters is Thomas Wickliffe Ockham (perhaps in memory of the medieval nominalist philosopher William Ockham-and/ or the medieval heretic John Wycliffe), a Jesuit particle physicist, professor at Fordham University, and author of two books about physics and religion, The

13 Winston P. Sander, "The Word to Space," in Mayo Mohs, ed., Other Worlds, Other Gods, (London: New English Library, 1976), 58-72.

14 James Morrow, Towing Jehovah (New York: Harcourt Blaze, 1994). 
Mechanics of Grace and Superstrings and Salvation. Ockham is commissioned by Pope Innocent XIV to participate in the towing of God's corpse by a tanker, the captain of which has already been given instructions by the archangel Raphael. Ockham boards the tanker on a journey in which all kind of outlandish events take place, such as the apparition of unknown islands, the intervention of angels, and airplane attacks from an aircraft carrier of the Second World War, until the corpse is laid in an ice vault. Finally, Ockham believes he has discovered an answer to the problem of God's death.

\section{The Jesuits and Other Topics}

After this brief summary of science-fiction novels with Jesuit characters, we may well ask what moved the authors to insert them, what image they present of Jesuits, whether this image corresponds to reality, and what topics are introduced because of the Jesuit presence, such as the problems of faith, Christianity, and the Catholic Church, which are not usually touched upon in this type of novel. First of all, the Jesuits in the novels are all scientists. This explains to some extent why Jesuits are chosen and not other sorts of priests, such as diocesans, Dominicans, or Franciscans, belonging to the Catholic Church; Jesuits have a traditional involvement in the natural sciences. The question, however, remains: why introduce such members of the Catholic Church in these novels? What image do they project of the church and of Christian faith in general?

With regard to the first question, about the image presented of Jesuits in general, it is difficult to answer as the characters are so different and the situations so distinct. In general, we may say that the image is a positive one, with a certain sympathy, corresponding to the popular picture of Jesuits as eager to investigate, open to modern ideas, and understanding of human situations. We cannot find more than that-for example, there is no clear expression of their spirituality. The Jesuit characters express what the authors think Jesuits are, sometimes with a distorted popular image, putting them in strange and complex circumstances of space journeys and contacts with aliens. Even in Russell's two novels, where a great number of Jesuits are found, the characters differ greatly from that of Superior General Vincenzo Giuliani to Brother Edward Behr. The main character Sandoz is from the beginning a tormented figure, especially after the trauma of his captivity and sexual slavery on the planet Rakhat, which he cannot overcome and ends in his departure from the Society. The other Jesuits present a great variety of attitudes during the long and complex story recounted in the two volumes of the novel. Russell has made a good effort to present a variety of positions in the different Jesuit characters, all of 
them dedicated to this space enterprise and their contact with the two species of the planet, moved always, as she insists, by "the greater glory of God."

Another example is Fr. Ruiz Sánchez in Bliss's novel who, faced with the behavior of the Lithian, finds himself in a continuous tension of conscience between the results of science and the demands of religious faith. He doubts whether their existence constitutes a negation of the need for God and even if they have been created by the evil spirit. The solution proposed by the pope of exorcizing the planet only increases Ruiz's problems of conscience.

The figure of the Jesuit paleontologist Pierre Teilhard de Chardin (1881-1955) with his vision of the world based on both science and Christian faith could have been a good model for the futuristic vision present in these novels; but he is hardly present in any of them. Only in Simmons's novel is Doré said to be a follower of "Saint Teilhard," who is supposed to have been already canonized.

In several novels, future society is presented as fully secularized, with Christianity reduced to a small sect in which the Jesuits are an active and prominent group. In Broderick's novel, Jesuits have even been expelled from the planet Earth. The contrast between the ideas of atheistic characters and those of the Jesuits sometimes contributes to interesting discussions. However, in general, there is no in-depth analysis of the situation. The Vatican and the pope and their relations with the Jesuits are also presented in some novels as an intriguing literary device.

\section{Conclusion}

In spite of the genre limitations of science fiction and, in general, authors' relative ignorance about Jesuits, the fact that they are used as leading characters in these novels is still of interest. There is an implicit recognition of their special relationship, as Jesuits, with science - a relationship not present in other men religious. Their condition as priests leads to the presentation of problems of religious faith and its relation to science, and occasionally about the structure of the church. For example, the contact of Jesuits with aliens in strange circumstances raises the problem of the existence of religious thought outside humanity. Thus, the Jesuit presence in these novels serves to introduce, although not always in an adequate way, topics that would not have been raised otherwise. 